\title{
Anti-inflammatory and anti-nociceptive activities of Fumaria indica whole plant extract in experimental animals
}

\author{
CHANDANA VENKATESWARA RAO* \\ ARTI RAJ VERMA \\ PRAKSH KUMAR GUPTA \\ MADHAVAN VIJAYAKUMAR
}

Pharmacognosy and Ethnopharmacology

Division, National Botanical Research

Institute, Rana Pratap Marg

Lucknow-226001, India

\begin{abstract}
The $50 \%$ ethanolic extract of Fumaria indica was investigated for its anti-inflammatory and antinociceptive potential in animal models. Oral administration of $F$. indica dry extract (100, 200 and $400 \mathrm{mg} \mathrm{kg}^{-1}$ ) exhibited dose dependent and significant anti-inflammatory activity in acute (carrageenean and histamine induced hind paw oedema, $p<0.05$ ) and chronic cotton pellet granuloma models of inflammation, $p<0.01)$. The extract (400 mg $\mathrm{kg}^{-1}$ ) exhibited maximum anti-inflammatory effects of 42.2 and $42.1 \%$ after $3 \mathrm{~h}$ with carrageenean and histamine, respectively. The same dose of extract showed 38.9\% reduction in granuloma mass in a chronic condition. A significant anti-nociceptive activity was evidenced in mice; $6.6-67.7 \%(p<0.01)$ protection in mechanical, 33.9$125.1 \%(p<0.05)$ protection in thermal induced pain and $22.2-73.9 \%(p<0.05)$ protection in acetic acid-induced writhing.
\end{abstract}

Keywords: Fumaria indica (Fumariaceae), anti-inflammatory activity, anti-nociceptive activity

Fumaria indica (Hausskn.) Pugsley, syn: F. parviflora Lam. (Fumariaceae) is a small, scandent, branched annual herb growing wild in plains and lower hills. The plant is considered to be diuretic, diaphoretic, anthelmintic, laxative and is used to purify blood and in liver obstruction in ethnopharmacology $(1,2)$. Pharmacological studies show that F. indica possesses antipyretic, antidiarrhoeal and hypoglycemic properties (3-5). It is a smooth muscles relaxant and has hydrocholeretic, by stimulating bile excretion, and hepatoprotective effects (6-10). Phytochemical investigation revealed the presence of alkaloids, viz. protopine (6), parfumine, cryptopine, copticine, fumariline (11), fumaramine, fumaritine, paprafumicin, paprarine, papracinine, papraline, reddeanine (12), fumarophycine (13), narlumicine, narceimine, narlumidine (14); steroids, viz. $\beta$-sitosterol, stigmasterol, campesterol; organic acids viz. caffeic acid and fumaric acid $(9,13)$.

As there is no reference in literature to the anti-inflammatory aspects, it was considered worthwhile to study the anti-inflammatory and anti-nociceptive activity of the $\mathrm{Fu}$ maria indica whole plant.

\footnotetext{
* Correspondence, e-mail: chvrao72@yahoo.com
} 
C. Venkateswara Rao et al:: Anti-inflammatory and anti-nociceptive activities of Fumaria indica whole plant extract in experimental animals, Acta Pharm. 57 (2007) 491-498.

\section{EXPERIMENTAL}

\section{Plant material and extraction}

Plants of $F$. indica were collected from the rural area around Lucknow, India. The plant material was identified, authenticated taxonomically and a voucher specimen was preserved in Pharmacognosy and Ethnopharmacology Division (NBR-21) for future reference. Air-dried powdered material of F. indica (1000 g) was exhaustively extracted with 10 volumes of $50 \%$ ethanol. This process of extraction was repeated four times, the extract was filtered, concentrated on rotavapour (Büchi, USA) and then freeze-dried (Freezone ${ }^{\circledR} 4.5$, Labconco, USA) under high vacuum $(1.33 \mathrm{~Pa})$ and at temperature of -40 $\pm 2{ }^{\circ} \mathrm{C}$ (yield $9.85 \%, \mathrm{~m} / \mathrm{m}$ ).

\section{High performance thin layer chromatography (HPTLC)}

The $50 \%$ ethanolic extract of F. indica was analyzed by TLC, which showed the presence of phenolics. Caffeic acid and 50\% ethanolic extract of $F$. indica were spotted using a Camag Linomat IV spotter on the precoated silica gel $60 / \mathrm{UV}_{254}$ HPTLC plates (Merck, India) as stationary phase. The plate was eluted with toluene/ethyl acetate/formic acid (70:30:10) as mobile phase. After development, the plates were dried and densitometrically scanned on a TLC scanner III at $284 \mathrm{~nm}$ using WinCat software (CAMAG, Switzerland); the peak area was recorded and the calibration curve was prepared by plotting the peak area against the concentration of caffeic acid applied.

\section{Animals}

Male Sprague-Dawley rats (150-175 g) and albino mice $(25-30 \mathrm{~g})$ were obtained from the animal colony of the National Laboratory Animal Centre, Lucknow, India. They were randomly distributed into groups and housed in cages (6 per cage) and maintained under standard conditions at $26 \pm 2{ }^{\circ} \mathrm{C}$ and relative humidity $44-56 \%$ and $10 \mathrm{~h}$ light $14 \mathrm{~h}$ dark cycles each day for one week before and during the experiments. All animals were fed the standard rodent pellet diet (Amrut, India) and drank water ad libitum. All studies were performed in accordance with the guidelines for the care and use of laboratory animals, as adopted and promulgated by the Institutional Animal Care Committee, CPCSEA, India.

\section{Anti-inflammatory activity of 50\% ethanolic extract of $\mathrm{F}$. indica}

The rats were divided into five groups of six animals each. The test groups received the dry extract of $F$. indica (suspended in 1\% caboxymethylcellulose, CMC) at doses of 100, 200 and $400 \mathrm{mg} \mathrm{kg}^{-1}$, p.o.; the reference group received phenylbutazone (100 mg kg-1, in $1 \% \mathrm{CMC}$, p.o.) as positive control and the negative control animals received the vehicle only (1\% CMC, $10 \mathrm{~mL} \mathrm{~kg}^{-1}$, p.o.).

Carrageenean induced paw oedema. - The test was used to determine the anti-inflammatory activity of the extract by the method of Winter et al. (17). The animals pretreated with extract or phenylbutazone one hour before were injected with $0.1 \mathrm{~mL}$ of $1 \% \lambda$ carra- 
C. Venkateswara Rao et al:: Anti-inflammatory and anti-nociceptive activities of Fumaria indica whole plant extract in experimental animals, Acta Pharm. 57 (2007) 491-498.

geenean (in 1\% CMC) solution into the sub-plantar side of right hind paw. Paw volume was measured by dislocation of the water column in a plethysmometer (Ugo Basile, Italy) immediately after $\lambda$ carrageenean application (time zero) and $3 \mathrm{~h}$ after the stimulus. Reduction in the paw volume compared to the vehicle-treated control animals was considered as anti-inflammatory response.

Histamine-induced hind paw oedema. - This experiment was conducted as per the methodology used by Parmar and Ghosh (16). Right hind paw oedema was induced by the sub plantar injection of $0.1 \mathrm{~mL}$ of histamine $\left(1 \mathrm{mg} \mathrm{mL}^{-1}\right.$ in $\left.1 \% \mathrm{CMC}\right)$. Extract and phenylbutazone were administered $1 \mathrm{~h}$ prior to the inflammatory insult. The paw volume compared to that of the negative control animals was recorded after $3 \mathrm{~h}$ and considered as anti-inflammatory response.

Cotton pellet-induced granuloma. - The test was performed on the rats using the cotton pellet induced granuloma method (17). The rats were anesthetized under light ether and an incision was made on the lumbar region by blunted forceps, a subcutaneous tunnel was made and a sterilized cotton pellet $(100 \pm 1 \mathrm{mg})$ was inserted in the groin area. Groups of 6 animals received either extract or phenylbutazone or vehicle (1\% CMC) orally for seven consecutive days from the day of cotton pellet insertion. On the eighth day animals were anesthetized again and cotton pellets were removed and dried to constant mass (18).

\section{Anti-nociceptive activity of $50 \%$ ethanolic extract of $\mathrm{F}$. indica}

Anti-nociceptive activity was assessed by analgesy meter induced pain (19), hot plate reaction time (20) and abdominal writhing test using acetic acid (21) applied to male albino mice. Animals of the negative control received the vehicle only (1\% CMC, $10 \mathrm{~mL}$ $\mathrm{kg}^{-1}$, p.o.).

Analgesy meter induced pain. - Analgesy meter induced pain was tested in mice using an analgesy-meter (Ugo Basile). This method involved the application of force to the paw using the analgesy meter, which exerts a force at a constant rate. The mice were gently placed between the plinth and plunger. The instrument was switched on and constant motor rate was used to drive the plunger onto the paw. When the mice struggled, the instrument was switched off and the force at which the animal felt pain was read on a scale. The pre and post treatment weight causing pain was determined for each mouse. F. indica extract as test drug $\left(100,200\right.$, and $400 \mathrm{mg} \mathrm{kg}^{-1}$, p.o.) and acetylsalicylic acid (ASA, $25 \mathrm{mg} \mathrm{kg}^{-1}$, p.o.) as reference drug in 1\% CMC were administered 30 min before the test.

Hot plate reaction time. - Mice were screened by being placed on a hot plate maintained at $55 \pm 1{ }^{\circ} \mathrm{C}$ and recording the reaction time in seconds for fore paw licking or jumping. Only mice that reacted within fifteen seconds and did not show large variation on three separate occasions, each fifteen minutes apart, were taken for the test. Reaction time (paw licking, jumping) was measured initially and $30 \mathrm{~min}$ after intraperitoneal injection of $10 \mathrm{mg} \mathrm{kg}^{-1}$ pentazocine (PZ) as a reference drug and F. indica extract in $1 \%$ CMC (100, 200, and $\left.400 \mathrm{mg} \mathrm{kg}^{-1}\right)(20)$. 
C. Venkateswara Rao et al.: Anti-inflammatory and anti-nociceptive activities of Fumaria indica whole plant extract in experimental animals, Acta Pharm. 57 (2007) 491-498.

Acetic acid-induced writhing test. - In the writhing test, $0.6 \%$ acetic acid $\left(10 \mathrm{mg} \mathrm{kg}^{-1}\right.$, i.p.) was injected and the number of writhes and stretching with a jerk of the hind limb were counted for a period of $15 \mathrm{~min}$. Acetylsalicylic acid (ASA, $25 \mathrm{mg} \mathrm{kg}^{-1}$, p.o.) or the $F$. indica extract in $1 \%$ CMC $\left(100,200\right.$, and $\left.400 \mathrm{mg} \mathrm{kg}^{-1}\right)$ were administered orally $30 \mathrm{~min}$ before acetic acid injection (21).

\section{Statistical analysis}

All the data are presented as mean \pm SEM and one-way analysis of variance (ANOVA) and Newman-Keuls Multiple Comparision Test were applied for determining the statistical significance between different groups.

\section{RESULTS AND DISCUSSION}

\section{Phytochemical screening}

Preliminary qualitative phytochemical screening of $F$. indica showed the presence of alkaloids, flavonoids, glycosides, tannins, saponins, steroids and triterpenoids.

Earlier studies on this plant by Sousek et al. (12) reported the presence of organic acids. Hence, we made an attempt to quantify the caffeic acid in F. indica.

Concentration of caffeic acid (396 $\mu \mathrm{g} \mathrm{g}^{-1}$ extract) present in $50 \%$ ethanolic extract of F. indica was estimated.

\section{Anti-inflammatory activity of $50 \%$ ethanolic extract of $\mathrm{F}$. indica}

Treatment with different doses of $F$. indica showed a dose-dependent inhibition of swelling caused by $\lambda$ carrageenean after $3 \mathrm{~h}$ equivalent to 13.6 to $42.2 \%$ protection in comparison with the negative control, whereas phenylbutazone at the dose of $100 \mathrm{mg}$

Table I. Effect of 50\% ethanolic extract of $\mathrm{F}$. indica on carrageenean and histamine induced paw oedema in rats

\begin{tabular}{lcccc}
\hline \multirow{2}{*}{ Treatment } & \multicolumn{2}{c}{ Carrageenean induced } & \multicolumn{2}{c}{ Histamine induced } \\
\cline { 2 - 5 } & $\begin{array}{c}\text { Paw volume } \\
(\mathrm{mL})\end{array}$ & $\begin{array}{c}\text { Inhibition } \\
(\%)\end{array}$ & $\begin{array}{c}\text { Paw volume } \\
(\mathrm{mL})\end{array}$ & $\begin{array}{c}\text { Inhibition } \\
(\%)\end{array}$ \\
\hline Negative control $(1 \% \mathrm{CMC}$, & $1.18 \pm 0.05$ & - & $1.26 \pm 0.03$ & - \\
$10 \mathrm{~mL} \mathrm{~kg}-1)$ & $1.02 \pm 0.04^{\mathrm{a}}$ & 13.6 & $1.11 \pm 0.05^{\mathrm{a}}$ & 11.2 \\
F. indica $\left(100 \mathrm{mg} \mathrm{kg}^{-1}\right)$ & $0.89 \pm 0.03^{\mathrm{b}}$ & 24.7 & $1.00 \pm 0.02^{\mathrm{b}}$ & 20.6 \\
F. indica $\left(200 \mathrm{mg} \mathrm{kg}^{-1}\right)$ & $0.67 \pm 0.03^{\mathrm{b}}$ & 43.2 & $0.73 \pm 0.03^{\mathrm{b}}$ & 42.1 \\
F. indica $\left(400 \mathrm{mg} \mathrm{kg}^{-1}\right)$ & & 44.1 & $0.71 \pm 0.06^{\mathrm{b}}$ & 43.2 \\
Phenylbutazone $\left(100 \mathrm{mg} \mathrm{kg}^{-1}\right)$ & $0.66 \pm 0.05^{\mathrm{b}}$ & & & \\
\hline
\end{tabular}

Mean \pm SEM for six rats per group.

a $p<0.05,{ }^{\mathrm{b}} p<0.001$ compared to negative control. 
C. Venkateswara Rao et al:: Anti-inflammatory and anti-nociceptive activities of Fumaria indica whole plant extract in experimental animals, Acta Pharm. 57 (2007) 491-498.

$\mathrm{kg}^{-1}$ showed $44.1 \%$ anti-inflammatory activity (Table I). The F. indica extract at doses of 100, 200 and $400 \mathrm{mg} \mathrm{kg}^{-1}$ reduced the oedema induced by histamine by 11.2 to $42.1 \%$ respectively, whereas phenylbutazone decreased by oedema $43.2 \%$ (Table I). The study of $F$. indica extract on cotton pellet granuloma in rats indicated that $F$. indica $(100,200$ and $400 \mathrm{mg} \mathrm{kg}^{-1}$, p.o.) significantly $(p<0.01)$ reduced the granuloma formation by percent inhibition of 16.7 to $38.9 \%$ compared to the control. Phenylbutazone showed significant $(p<0.001)$ inhibition of granuloma formation by percent inhibition of $40.1 \%$ (Table II).

Table II. Effect of 50\% ethanolic extract of F. indica on cotton pellet induced granuloma in rats

\begin{tabular}{lcc}
\hline Treatment & Dry mass $(\mathrm{mg})$ & Inhibition $(\%)$ \\
\hline Negative control $\left(1 \% \mathrm{CMC}, 10 \mathrm{~mL} \mathrm{~kg}^{-1}\right)$ & $36.8 \pm 1.9$ & - \\
F. indica $\left(100 \mathrm{mg} \mathrm{kg}^{-1}\right)$ & $30.6 \pm 1.2^{\mathrm{a}}$ & 16.9 \\
F. indica $\left(200 \mathrm{mg} \mathrm{kg}^{-1}\right)$ & $27.3 \pm 1.6^{\mathrm{b}}$ & 26.0 \\
F. indica $\left(400 \mathrm{mg} \mathrm{kg}^{-1}\right)$ & $22.5 \pm 1.5^{\mathrm{b}}$ & 38.9 \\
Phenylbutazone $\left(100 \mathrm{mg} \mathrm{kg}^{-1}\right)$ & $22.1 \pm 1.1^{\mathrm{b}}$ & 40.1 \\
\hline
\end{tabular}

Mean \pm SEM for six rats per group.

a $p<0.01,{ }^{\mathrm{b}} p<0.001$ compared to negative control.

\section{Anti-nociceptive activity of $50 \%$ ethanolic extract of $\mathrm{F}$. indica}

The experimental data of the force-induced pain indicates that the mice treated with F. indica extract exhibited resistance against pain after 30 min equivalent to 17.4 to $57.3 \%$ at different doses compared to the control (Fig. 1). F. indica extract at the dose of $100 \mathrm{mg} \mathrm{kg}^{-1}$ increased the hot plate reaction time by $33.9 \%$. However, dose levels of 200 and $400 \mathrm{mg}$ $\mathrm{kg}^{-1}$ increased the reaction time significantly $(p<0.01)$ and percent protection by $73.2 \%$ and $125.1 \%$, respectively (Fig. 2). F. indica extract showed inhibition of the writhing response induced by acetic acid dose dependently (100, 200 and $400 \mathrm{mg} \mathrm{kg}^{-1}$ ), which resulted in greater inhibition of stretching episodes; the protection ranged from 27.0 to $53.5 \%$, whereas and acetylsalicylic acid blocked the writhing response by $63.1 \%$ (Table III).

Fig. 1. Effect of 50\% ethanolic extract of $F$. indica on force induced pain in mice.

Mean \pm SEM for six mice per group. a $p<0.01,{ }^{b} p<0.001$ compared to negative control.

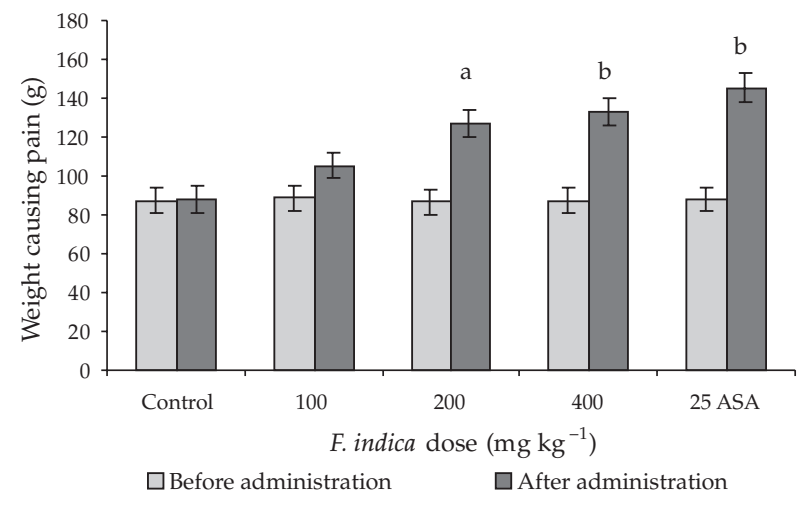


Fig. 2. Effect of $50 \%$ ethanolic extract of $F$. indica on hot plate reaction time in mice.

Mean \pm SEM for six mice per group. ${ }^{\mathrm{a}} p<0.05,{ }^{\mathrm{b}} p<0.01,{ }^{\mathrm{c}} p<0.001 \mathrm{com}-$ pared to negative control.

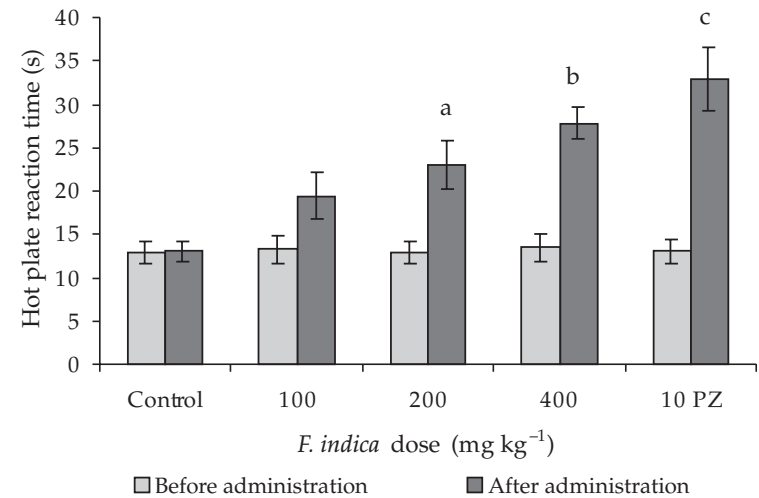

The present study demonstrates the anti-inflammatory activity of the $50 \%$ ethanolic extract of $F$. indica in different models of inflammation-acute exudative and proliferative phases of inflammation. Dose of $400 \mathrm{mg} \mathrm{kg}^{-1}$ shows anti-inflammatory and anti-nociceptive effect to standard drugs. Caffeic acid is one of the phenolics present in F. indica, which was reported to possess anti-inflammatory activity (22). On the other hand, $\beta$-sitosterol has also been reported as an anti-inflammatory, analgesic and antipyretic agent $(23,24)$. Therefore, caffeic acid and $\beta$-sitosterol may be responsible for the anti-inflammatory and anti-nociceptive effects exhibited by F. indica. The ability of the F. indica extract in analgesic activity may be due to the involvement of prostaglandins and other mediators in a different order of magnitudes. The capacity of prostaglandin to sensitize pain receptors to mechanical and chemical stimulation appears to result from a lowering of the threshold after $F$. indica treatment.

Table III. Effect of 50\% ethanolic extract of F. indica on acetic acid induced writhing in mice

\begin{tabular}{lcc}
\hline Treatment & Number of writhings & Inhibition (\%) \\
\hline Negative control $\left(1 \% \mathrm{CMC}, 10 \mathrm{~mL} \mathrm{~kg}^{-1}\right)$ & $26.7 \pm 2.7$ & - \\
F. indica $\left(100 \mathrm{mg} \mathrm{kg}^{-1}\right)$ & $19.5 \pm 2.2^{\mathrm{a}}$ & 27.0 \\
F. indica $\left(200 \mathrm{mg} \mathrm{kg}^{-1}\right)$ & $15.3 \pm 1.2^{\mathrm{b}}$ & 42.6 \\
F. indica $\left(400 \mathrm{mg} \mathrm{kg}^{-1}\right)$ & $12.4 \pm 1.7^{\mathrm{c}}$ & 53.5 \\
Acetylsalicylic acid $\left(25 \mathrm{mg} \mathrm{kg}^{-1}\right)$ & $9.9 \pm 1.6^{\mathrm{c}}$ & 63.1 \\
\hline
\end{tabular}

Mean \pm SEM for six mice per group.

${ }^{\mathrm{a}} p<0.05,{ }^{\mathrm{b}} p<0.01, \mathrm{c} p<0.001$ compared to negative control.

\section{CONCLUSIONS}

Based on the present study, it can be concluded that $F$. indica has potential anti-inflammatory activity against both exudative (carrageenean and histamine induced in- 
C. Venkateswara Rao et al.: Anti-inflammatory and anti-nociceptive activities of Fumaria indica whole plant extract in experimental animals, Acta Pharm. 57 (2007) 491-498.

flammation) and proliferative (cotton pellet induced granuloma) phases of inflammation; the extract also showed anti-nociceptive activity, mediated both centrally and peripherally. F. indica extract significantly raised the pain threshold. This offers a new perspective in the treatment of pain. Further studies are in progress and are aimed to identify all active constituents responsible for the anti-inflammatory and anti-nociceptive properties.

Acknowledgements. - These studies were supported in part by grants from the Indian Council of Medical Research (ICMR), New Delhi. Authors are also thankful to Director NBRI for providing necessary facilities.

\section{REFERENCES}

1. R. N. Chopra, S. L. Nayar and S. N. Chopra, Glossary of Indian Medicinal Plants, National Institute of Science Communication and Information Resources (CSIR), New Delhi 2002, p. 122.

2. P. Hordgen, H. Hertzberg, J. Helimann, W. Langhans and V. Maurer, The anthelmintic efficiency of five plant products against gastrointestinal trichostrongylids in artificially infected lambs, Vet. Parasitol. 117 (2003) 51-60; DOI:10.1016/j.vetpar.2003.07.027.

3. S. G. Khattak, S. N. Gilani and M. Ikram, Antipyretic studies on some indigenous Pakistani medicinal plants, J. Ethnopharmacol. 14 (1985) 45-51; DOI:10.1016/0378-8741(85)90027-3.

4. A. H. Gilani, S. Bashir, K. H. Janbaz and A. Khan, Pharmacological basis for the use of Fumaria indica in constipation and diarrhea, J. Ethnopharmacol. 96 (2005) 585-589; DOI:10.1016/j.jep.2004. 10.010 .

5. M. S. Akhtar, Q. M. Khan and T. Khaliq, Effect of Euphorbia prostrate and Fumaria indica in normoglycemic and alloxan-treated hyperglycemic rabbits, Planta Med, 50 (1984) 138-142; DOI: 10. 1055/s-2007-969653.

6. V. B. Pandey, B. Das Gupta, S. K. Bhattacharya, R. Lal and P. K. Das, Chemistry and pharmacology of the major alkaloid of Fumaria indica, Curr. Sci. 40 (1971) 455-457.

7. A. H. Gilani, K. H. Janbaz and M. S. Akhtar, Selective protective effect of the extract from $F u$ maria parviflora on paracetamol-induced hepatotoxicity, Gen. Pharmacol. 27 (1996) 979-983; DOI: 10.1016/0306-3623(95)02140-X.

8. S. R. Nimbkar, A. R. Juvekar and S. N. Jogalekar, Hepatoprotective activity of Fumaria indica in hepatotoxicity induced by anti-tubercular drugs treatment, Indian Drugs 37 (2000) 537-542.

9. K. S. Rao and S. H. Mishra, Hepatopotective activity of whole plants of Fumaria indica, Indian J. Pharm. Sci. 59 (1997) 165-170.

10. K. S. Rao and S. H. Mishra, Anti hepatotoxic activity of monomethyl fumarate isolated from Fumaria indica, J. Ethnopharmacol. 60 (1998) 207-213; DOI: 10.1016/S0378-8741(97)00149-9.

11. M. E. Popova, V. Simanek, L. Dolejis, B. Smysl and V. Preininger, Alkaloids from Fumaria parviflora and Fumaria kralikii, Planta Med. 45 (1982) 120-122; DOI: 10.1055/s-2007-971259.

12. Atta-ur-Rahman, M. K. Bhatti, M. I. Choudhary and S. K. Ahmad, Alkaloidal constituent of Fumaria indica, Phytochemistry 40 (1995) 593-596; DOI: 10.1016/0031-9422(95)00038-9.

13. J. Sousek, D. Guedon, T. Adam, H. Bochorakova, E. Taborska, I. Valka and V. Simanek, Alkaloids and organic acids content of eight Fumaria species, Phytochem. Anal. 10 (1999) 6-11; DOI: 10.1002/(SICI)1099-1565(199901/02)10:1<6::AID-PCA431>3.0.CO;2-0.

14. V. K. Tripathi and V. B. Pandey, Stem alkaloids of Fumaria indica, Phytochemistry 31 (1992) 21882189; DOI: 10.1016/0031-9422(92)80401-Y. 
C. Venkateswara Rao et al:: Anti-inflammatory and anti-nociceptive activities of Fumaria indica whole plant extract in experimental animals, Acta Pharm. 57 (2007) 491-498.

15. C. A. Winter, E. A. Risley and G. W. Nuss, Carrageenin induced oedema in hind paw of the rats as an assay for anti-inflammatory drugs, Proc. Soc. Exp. Biol. Med. 111 (1962) 544-547.

16. N. S. Parmar and S. Ghosh, Anti-inflammatory activity of Gossypin, a bioflavonoid isolated from Hibiscus vitifolius Linn, Indian J. Pharmacol. 10 (1978) 277-293.

17. C. A. Winter and C. C. Porter, Effect of alteration in side chain upon anti-inflammatory and liver glycogen activities in hydrocortisone esters, J. Am. Pharm. Assoc. 46 (1957) 515-519.

18. U. K. Sheth, N. K. Dadkar, G. Kamat and G. Usha, Selected Topics in Experimental Pharmacology, The Kothari Book Depot, Bombay 1972, p. 194.

19. R. E. Rodriguez, F. D. Rodriguez, M. P. Sacristan, J. L. Torres, F. Reig, J. G. Anton and G. Valencia, Antinociceptive activity of glycosidic enkephalin analogues, Psychopharmacology 101 (1990) 222-225; DOI: 10.1007 /BF02244130.

20. G. Wolfe and A. D. MacDonald, The evaluation of the analgesics action of pethidine hydrochloride (DEMEROL), J. Pharmacol. Exp. Ther. 80 (1944) 300-307.

21. L. B. Witkin, C. F. Huebner, F. Galdi, E. O. Keefe, P. Spitaletta and A. J. Plumer, Pharmacognosy of 2 amino-indane hydrochloride (SU 8629). A potent non-nacrotic analgesic, J. Pharmacol. Exp. Ther. 133 (1961) 400-408.

22. M. A. Fernandez, M. T. Saenz and M. D. Garcia, Anti-inflammatory activity in rats and mice of phenolic acids isolated from Scrophularia frutescens. J. Pharm. Pharmacol. 50 (1998) 1183-1186.

23. I. M. Villasenor, J. Angelada, A. P. Canlas and D. Echegoyen, Bioactivity studies on beta-sitosterol and its glucoside, Phytother. Res. 16 (2002) 417-421. DOI: 10.1002/ptr.910.

24. A. R. S. Santos, R. Niero, V. Cechinel Filho, R. A. Yunes, M. G. Pizzolatti, F. Delle Monache and J. B. Calixto, Antinociceptive properties of steroids isolated from Phyllanthus corcovadensis in mice, Planta Med. 61 (1995) 329-332; DOI: 10.1055/s-2006-958093.

\section{$S A \check{Z} E T A K$}

\section{Protuupalno i analgetsko djelovanje ekstrakta cijele biljke Fumaria indica na eksperimentalnim životinjama}

CHANDANA VENKATESWARARAO RAO, ARTI RAJ VERMA, PRAKSH KUMAR GUPTA I MADHAVAN VIJAYAKUMAR

$\mathrm{Na}$ animalnom modelu ispitivano je protuupalno i analgetsko djelovanje ekstrakta biljke Fumaria indica sa 50\%-tnim etanolnom. Peroralna primjena suhog ekstrakta $F$. indica (100, 200 i $400 \mathrm{mg} \mathrm{kg}^{-1}$ ) pokazuje značajno i o dozi ovisno protuupalno djelovanje na akutni (edem šape uzrokovan karagenom i histaminom, $p<0.05$ ) i kronični upalni proces (granulomi uzrokovani pamučnim peletama, $p<0.01$ ). Najveći protuupalni učinak u karagenskom, odnosno histaminskom testu od 42,2 i 42,1\% dobiven je s dozom $400 \mathrm{mg} \mathrm{kg}^{-1}$ nakon $3 \mathrm{~h}$. Ista doza ekstrakta pokazala je 38,9\% smanjenje mase granuloma. Značajno analgetsko djelovanje dokazano je pokusima na miševima: 6,6-67,7\% ( $p$ $<0,01)$ zaštita od mehanički izazvane boli, 33,9-125,1\% $(p<0,05)$ zaštita od termički izazvane boli i $22,2-73,9 \%(p<0,05)$ zaštita od kemijski izazvane boli octenom kiselinom.

Ključne riječi: Fumaria indica (Fumariaceae), protuupalno djelovanje, analgetsko djelovanje

Pharmacognosy and Ethnopharmacology Division, National Botanical Research Institute, Rana Pratap Marg, Lucknow-226 001, India 